\title{
Selective oxidation of methane to methanol using supported AuPd catalysts prepared by stabiliser-free sol-immobilisation
}

Christopher Williams ${ }^{[a]}$, James H. Carter ${ }^{[a]}$, Nicholas F. Dummer ${ }^{[a]}$, Y. Kit Chow ${ }^{[a]}$, David J. Morgan $^{[a]}$,Sara Yacob ${ }^{[b]}$, Pedro Serna ${ }^{[b]}$, David J. Willock ${ }^{[a]}$, Randall J. Meyer ${ }^{[b]}$, Stuart H. Taylor $^{[a]}$ and Graham J. Hutchings*[a]

[a] Cardiff Catalysis Institute, School of Chemistry, Cardiff University, CF10 3AT

[b] ExxonMobil Research and Engineering Company, Corporate Strategic Research, Annandale, NJ 08801, USA

*Corresponding email: hutch@cardiff.ac.uk 


\begin{abstract}
The selective oxidation of methane to methanol, using $\mathrm{H}_{2} \mathrm{O}_{2}$, under mild reaction conditions was studied using bimetallic 1 wt. $\% \mathrm{AuPd} / \mathrm{TiO}_{2}$ prepared by stabiliser-free sol-immobilisation. The as-prepared catalysts exhibited low, unselective oxidation activity and deleterious $\mathrm{H}_{2} \mathrm{O}_{2}$ decomposition, which was ascribed to the small mean particle size of the supported AuPd nanoparticles. Heat treatments were employed to facilitate particle size growth, yielding an improvement in the catalyst turn-over-frequency and decreasing the $\mathrm{H}_{2} \mathrm{O}_{2}$ decomposition rate. The effect of support phase was studied by preparing a range of AuPd catalysts supported on rutile $\mathrm{TiO}_{2}$. The low surface area rutile $\mathrm{TiO}_{2}$ yielded catalysts with effective oxygenate production, but poor $\mathrm{H}_{2} \mathrm{O}_{2}$ utilisation. The influence of the rutile- $\mathrm{TiO}_{2}$ support was investigated further by producing catalysts with a lower metal loading to maintain a consistent metal loading per $\mathrm{m}^{2}$ to the $1 \mathrm{wt} . \% \mathrm{AuPd} / \mathrm{P} 25 \mathrm{TiO}_{2}$ catalyst. When calcined at 800 ${ }^{\circ} \mathrm{C}$ the 0.13 wt.\% AuPd catalyst demonstrated significantly improved turn-over frequency of $103 \mathrm{~h}^{-1}$. In contrast, the turn-over frequency was found to be $c a .2 \mathrm{~h}^{-1}$ for the rutile-supported 1 wt. \% AuPd catalyst calcined at $800^{\circ} \mathrm{C}$. The catalysts were probed by electron microscopy and XPS to understand the influence of particle size and oxidation state on the utilisation of $\mathrm{H}_{2} \mathrm{O}_{2}$ and oxygenate productivity. This work shows that the key to highly active catalysts involves the prevention of deleterious $\mathrm{H}_{2} \mathrm{O}_{2}$ decomposition and this can be achieved through carefully controlling the nanoparticle size, metal loading and metal oxidation state.
\end{abstract}

Keywords: methane, $\mathrm{C}-\mathrm{H}$, methanol, AuPd, particle size, partial methane oxidation 


\section{Introduction}

The direct oxidation of methane to methanol is a key challenge within the scientific community. ${ }^{1,2}$ However, the direct transformation to methanol is complicated by the intrinsic inertness of methane, which lacks a dipole moment and usually requires harsh conditions for the activation of the kinetically stable $\mathrm{C}-\mathrm{H}$ bond $\left(\Delta \mathrm{H}_{\mathrm{C}-\mathrm{H}}=440 \mathrm{~kJ} \mathrm{~mol}^{-1}\right) \cdot{ }^{3}$ Current industrial methanol production is an energy-intensive and an indirect process that converts methane to synthesis gas before further conversion to methanol and other bulk chemicals. ${ }^{4,5}$ This process demonstrates high selectivity towards the desired products producing 85 million metric tonnes of methanol per annum as well as other valuable commodities. ${ }^{6}$

A single step approach, applicable under low reaction temperature would therefore drastically reduce processing costs for the production of methanol. Additionally, both affordable and readily available, natural gas has the potential to be an alternative feedstock for chemicals and high value fuels, reducing the global dependence and prolonging current petroleum reserves. Natural gas is a viable prospect for an abundant feedstock with proven reserves of ca.190 trillion cubic metres. ${ }^{7}$ Furthermore, with many natural gas reserves found in remote locations, direct conversion to methanol at the point of extraction would provide a feedstock with reduced hazards and transportation costs.

Homogeneous catalytic applications have provided important information for low temperature approaches, active site regeneration and high selectivities. However, typically these processes require harsh reaction conditions or sacrificial reagents. ${ }^{8-11}$ Contrastingly, Hutchings and co-workers ${ }^{12}$ have reported the use of an environmentally benign $\mathrm{H}_{2} \mathrm{O}: \mathrm{H}_{2} \mathrm{O}_{2}$ system, efficiently oxidising methane to methanol under low reaction temperatures $\left(50^{\circ} \mathrm{C}\right)$. The use of Fe-ZSM5 was inspired by methane mono-oxygenase, which carries out a one-step oxidation of methane to methanol under mild, aqueous conditions. The Fe- and $\mathrm{Cu}$ - promoted Fe-ZSM5 catalysts demonstrated considerable activity for the oxidation of methane to methanol, achieving turnover frequencies (TOFs) of $>2200 \mathrm{~h}^{-1}$ and methanol selectivities above $80 \%{ }^{13}$

Alternatively, $\mathrm{C}-\mathrm{H}$ bond activation has been extensively studied using noble metal catalysts such as AuPd. ${ }^{14,15}$ Kesavan et al. ${ }^{16}$ reported the selective oxidation of the methyl group $\mathrm{C}-\mathrm{H}$ bonds in toluene over $\mathrm{TiO}_{2}$ - and carbon- supported AuPd catalysts using $\mathrm{O}_{2}$. Demonstrating high selectivity towards benzyl benzoate the differences in catalytic activity were attributed 
to different AuPd morphologies due to support-metal interactions. However, direct oxidation of methane to methanol with oxygen has proved a significant challenge. Ab Rahim et al. ${ }^{17,18}$ reported on the systematic study of $\mathrm{AuPd} / \mathrm{TiO}_{2}$ catalysts for efficient formation of methanol from methane with $\mathrm{H}_{2} \mathrm{O}_{2}$. These catalysts were synthesized by wet impregnation from chloride precursors onto the support, typically producing a broad range of particle sizes. The catalysts were comprised of alloyed AuPd nanoparticles, with particle sizes ranging from 5-20 $\mathrm{nm}$ and Au-rich nanoparticles $100-200 \mathrm{~nm}$ in size. ${ }^{19}$ The presence of sub-nm AuPd particles and clusters of Pd were also identified, reflecting the poor control of metal dispersion and speciation provided by wet impregnation. Even so, these $\mathrm{AuPd} / \mathrm{TiO}_{2}$ catalysts showed moderate activity, demonstrating the highest methanol (49\%) and oxygenate selectivity $(90 \%)$ of supports investigated, including carbon..$^{20}$

Despite exhibiting lower oxygenate formation, TOF and methanol selectivity than their FeZSM-5 counterparts, AuPd catalysts are an attractive class of catalyst because they could be developed to generate $\mathrm{H}_{2} \mathrm{O}_{2}$ in situ from $\mathrm{H}_{2}$ and $\mathrm{O}_{2}$. Ab Rahim et al., applied this approach with $\mathrm{AuPd} / \mathrm{TiO}_{2}$, reporting a productivity of $0.50 \mathrm{~mol} \mathrm{~kg}_{\mathrm{cat}}{ }^{-1} \mathrm{~h}^{-1}$ compared to $0.116 \mathrm{~mol} \mathrm{~kg}_{\mathrm{cat}^{-1}}$ $\mathrm{h}^{-1}$ when similar amounts of preformed $\mathrm{H}_{2} \mathrm{O}_{2}(250 \mu \mathrm{mol}) .{ }^{18}$ However, an improvement in methanol selectivity (68\%) and three-fold improvement in $\mathrm{H}_{2} \mathrm{O}_{2}$ reactivity were observed during in situ peroxide generation.

Recently Agarwal et al. ${ }^{21}$ showed significant improvements in activity when unsupported AuPd nanoparticles were used. Colloidal AuPd prepared using poly(vinyl pyrrolidine) showed high oxygenate productivity with preformed $\mathrm{H}_{2} \mathrm{O}_{2}\left(29.4 \mathrm{~mol} \mathrm{~kg}_{\mathrm{cat}^{-1}} \mathrm{~h}^{-1}\right)$. Notably, the introduction of oxygen with preformed $\mathrm{H}_{2} \mathrm{O}_{2}$ resulted in a substantial increase in oxygenate productivity to $53.6 \mathrm{~mol} \mathrm{~kg}_{\mathrm{cat}}{ }^{-1} \mathrm{~h}^{-1}$. The use of ${ }^{18} \mathrm{O}_{2}$ demonstrated significant incorporation of the gas phase $\mathrm{O}_{2}$ into the methanol produced (70\%). Crucially however, the rate of $\mathrm{H}_{2} \mathrm{O}_{2}$ decomposition was drastically reduced by elimination of a metal-support interaction and the resulting high productivity was attributed to the controlled $\mathrm{H}_{2} \mathrm{O}_{2}$ breakdown.

Industrially, in situ generation of $\mathrm{H}_{2} \mathrm{O}_{2}$ is more desirable than using pre-formed $\mathrm{H}_{2} \mathrm{O}_{2}$ as the oxidant, a necessary requirement for the use of MFI-zeolite based catalysts. In order to realise this application, a solid understanding of the chemical reactivity of $\mathrm{H}_{2} \mathrm{O}_{2}$ with supported AuPd catalysts is required. In contrast to impregnation techniques, catalyst synthesis by solimmobilisation (SI) facilitates the control of particle sizes, composition and morphology. ${ }^{22,23}$ 
This methodology has been used to tune catalyst activity and enhance product selectivity for several reactions, including benzyl alcohol oxidation and hydrogenation of furfural. ${ }^{24,25}$ In this investigation, the role of AuPd particle size, support and oxidation state is considered for the selective oxidation of methane to methanol using added $\mathrm{H}_{2} \mathrm{O}_{2}$. The particle size distribution of AuPd is controlled using SI and carefully manipulated to evaluate the influence of nanoparticle size on the effective utilisation of $\mathrm{H}_{2} \mathrm{O}_{2}$ and the production of methanol. 


\section{Experimental}

Preparation of $\mathrm{AuPd} / \mathrm{TiO}_{2}$ by sol-immobilisation

For 0.5 wt.\% Au-0.5 wt.\% Pd/TiO 2 , aqueous solutions of $\mathrm{HAuCl}_{4} . \mathrm{xH}_{2} \mathrm{O}$ (Aldrich $99.9 \% 1.667 \mathrm{~mL}$, 12.25 $\mathrm{mg} \mathrm{mL}^{-1}$ ) and $\mathrm{PdCl}_{2}$ (Aldrich $0.816 \mathrm{~mL}, 6 \mathrm{mg} \mathrm{mL}^{-1}$ ) were added to deionised water (800 $\mathrm{mL}$ ) under vigorous stirring at room temperature. The resulting solution was stirred for $2 \mathrm{~min}$ before the addition of freshly prepared $\mathrm{NaBH}_{4}(7.23 \mathrm{~mL}, 0.1 \mathrm{M})$ such that the molar ratio of $\mathrm{NaBH}_{4}$ to metal was $5: 1 \cdot{ }^{16,26}$ Upon the addition of $\mathrm{NaBH}_{4}$, the mixture turned dark brown/black and was then vigorously stirred for $30 \mathrm{~min}$ before addition of the $\mathrm{TiO}_{2}$ (P25 Degussa, $1.98 \mathrm{~g}$ ) support. The solution was acidified to $\mathrm{pH} 1$ after $1 \mathrm{~min}$ by drop-wise addition of sulfuric acid (>95\%) and stirred for $1 \mathrm{~h}$. The suspension was then filtered under vacuum and washed thoroughly with distilled water and then dried in a conventional oven for $16 \mathrm{~h}$ at $110{ }^{\circ} \mathrm{C}$. Calcinations were performed under static air at various temperatures for $3 \mathrm{~h}$ (ramp rate of $\left.20{ }^{\circ} \mathrm{C} \mathrm{min}-1\right)$, while reduction of the catalysts was carried out under flowing $5 \% \mathrm{H}_{2} / \mathrm{Ar}$ for $4 \mathrm{~h}\left(\right.$ ramp rate $\left.=10^{\circ} \mathrm{C} \mathrm{min}^{-1}\right)$.

A similar method was followed for the preparation of 0.065 wt.\% Au- 0.065 wt.\% Pd/rutile

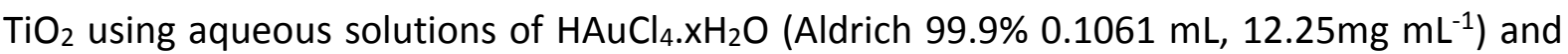
$\mathrm{PdCl}_{2}$ (Aldrich 99.9\% $0.2167 \mathrm{~mL}, 6 \mathrm{mg} \mathrm{mL}^{-1}$ ), with pre-calcined $\mathrm{TiO}_{2}$ (P25 Degussa, $1.9974 \mathrm{~g}$ ) support.

In order to help differentiate between the prepared catalysts, the following nomenclature was adopted: "metal loading\% AuPd/phase of $\mathrm{TiO}_{2}$, temperature of preparation, calcination temperature". For example, a 1 wt. \% AuPd catalyst prepared at room temperature on P25 $\mathrm{TiO}_{2}$ and calcined at $800{ }^{\circ} \mathrm{C}$ would be abbreviated as $1 \%$ AuPd/P25-RT-800. A table of the catalysts prepared and their abbreviations is presented in the Supporting Information (Table S1).

Oxidation of methane using $\mathrm{H}_{2} \mathrm{O}_{2}$

The oxidation of methane was carried out using a $50 \mathrm{~mL}$ Parr stainless steel autoclave reactor. The autoclave was fitted with a removable Teflon liner ( $35 \mathrm{~mL}$ volume). 
Reactions were carried out using a $10 \mathrm{~mL}$ reaction mixture comprising an aqueous solution of $\mathrm{H}_{2} \mathrm{O}_{2}(10 \mathrm{~mL}, 0.5 \mathrm{M}, 5000 \mu \mathrm{mol})$ and the catalyst $(10 \mathrm{mg})$. Prior to use the reactor was purged with methane to remove residual air before being pressurised with methane to 30.5 bar. The autoclave was then heated to the desired reaction temperature $\left(50{ }^{\circ} \mathrm{C}\right)$ using the pre-set programme. At reaction temperature ( $t=0 \mathrm{~min})$, the solution was vigorously stirred at 1500 RPM and both heating and stirring were maintained for the required length (typically $30 \mathrm{~min}$ ). Following this, the stirring was stopped and the temperature was reduced to $10{ }^{\circ} \mathrm{C}$ using an ice bath to minimise the loss of volatile products. Gaseous samples were removed by extraction into a gas bag for analysis via gas chromatography. The Varian-GC was equipped with a CP-SIL5CB column (50 m, $0.33 \mathrm{~mm}$ internal diameter) fitted with a methaniser and analysed by a flame ionisation detector (FID). The reaction mixture was filtered to remove catalyst particulates and analysed by ${ }^{1} \mathrm{H}$ NMR, using a Bruker $500 \mathrm{MHz}$ Ultra-shield NMR spectrometer. A sample NMR spectrum is presented in Figure $\mathrm{S} 1$. All ${ }^{1} \mathrm{H}$ NMR samples were analysed against a calibrated insert containing tetramethylsilane (TMS) in deuterated chloroform (99.9\% D). The remaining $\mathrm{H}_{2} \mathrm{O}_{2}$ was determined by titration with acidified $\mathrm{Ce}\left(\mathrm{SO}_{4}\right)_{2}$.

Reactions to determine the decomposition rate of $\mathrm{H}_{2} \mathrm{O}_{2}$ over catalyst samples

The decomposition of $\mathrm{H}_{2} \mathrm{O}_{2}$ was carried out in a $35 \mathrm{~mL}$ glass vial. A typical reaction was carried out using $10 \mathrm{~mL}$ reaction mixture comprising an aqueous solution of $\mathrm{H}_{2} \mathrm{O}_{2}(10 \mathrm{~mL}, 0.5 \mathrm{M}, 5000$ $\mu \mathrm{mol})$ and a measured amount of solid catalyst (10 mg). At intervals, $\mathrm{H}_{2} \mathrm{O}_{2}$ concentration was determined by titration of $0.1 \mathrm{~mL}$ sample of reaction solution against an acidified $\mathrm{Ce}\left(\mathrm{SO}_{4}\right)_{2}$ solution of known concentration using one drop of ferroin indicator $(0.025 \mathrm{M})$. The reactions were carried out at room temperature, with stirring maintained at 1000 RPM.

\section{Catalyst Characterisation}

Powder X-ray Diffraction (XRD) patterns were collected using a PANalytical X'PertPRO X-ray diffractometer, with $\mathrm{Cu} \mathrm{K}_{\alpha}$ radiation source $(\lambda=0.154 \mathrm{~nm})$ and a Ni filter at ambient conditions. Samples were recorded between $15-80^{\circ}$ at $40 \mathrm{kV}$ and $40 \mathrm{~mA}$ with step sizes of $0.0167^{\circ}$.Transmission electron microscopy (TEM) was performed on a JEOL JEM-2100 
operating at $200 \mathrm{kV}$. Samples were prepared by dispersion in ethanol by sonication and deposited onto 300 mesh copper grids coated with holey carbon film. X-ray photoelectron spectroscopy (XPS) was performed using a Kratos Axis Ultra DLD spectrometer, using monochromatic Al $K_{\alpha} \mathrm{X}$-ray source operating at $120 \mathrm{~W}$. Data was collected with pass energies of $160 \mathrm{eV}$ for survey spectra, and $40 \mathrm{eV}$ for higher resolution scans. The system was operated in the Hybrid mode, using a combination of magnetic immersion and electrostatic lenses and acquired over an area approximately $300 \times 700 \mu \mathrm{m}^{2}$. A magnetically confined charge compensation system was used to minimize charging of the sample surface, and all spectra were taken with a $90^{\circ}$ take of angle. A base pressure of $c a .1 \times 10^{-9}$ Torr was maintained during collection of the spectra. Each spectrum was calibrated against adventitious carbon, using the C 1s region, to $284.8 \mathrm{eV}$ and CasaXPS was used for peak fitting, with integrated areas corrected for elemental sensitivity using modified Wagner factors as supplied by Kratos. Experimental binding energies are reported with confidence of $\pm 0.2 \mathrm{eV}$. To assess any reduction of $\mathrm{Pd}(\mathrm{II})$ species during analysis, $\mathrm{Pd}(3 \mathrm{~d}) / \mathrm{Au}(4 \mathrm{~d})$ spectra were acquired both at the start and again at the end of analysis, with negligible reduction of $\mathrm{Pd}(\mathrm{II})$ noted during the total analysis period.

Surface area measurements were performed at $-196{ }^{\circ} \mathrm{C}$ on a Quantachrome Quadrasorb SI instrument after each sample was evacuated for $1 \mathrm{~h}$ at $120^{\circ} \mathrm{C}$. Surface areas were calculated using Brunauer-Emmet-Teller (BET) theory over the range $\mathrm{P} / \mathrm{PO}=0.05-0.2$.

Energy dispersive X-ray analysis (EDX) was performed on a Tescan Maia3 field emission gun scanning electron microscope (FEG-SEM) fitted with an Oxford Instruments XMAXN 80 Images were acquired using the secondary electron and backscattered electron detectors. Samples were dispersed as a powder onto adhesive carbon Leit discs mounted onto aluminium stubs.

\section{Results and Discussion}

The effect of the nanoparticle size

To evaluate the effect of supported metal particle size, a series of 1 wt. \% AuPd/TiO 2 (P25) catalysts were prepared using stabiliser-free sol-immobilisation. This technique can produce supported catalysts with a narrow nanoparticle size distribution which can then be manipulated with post-synthesis heat treatments. ${ }^{27}$ Furthermore, the deposition temperature during catalyst synthesis was previously reported to affect the size of the 
nanoparticles. Rogers et al..$^{28}$ previously reported an increase in particle size for poly(vinyl alcohol) stabilised Au nanoparticles after increasing the temperature during colloidal deposition from 25 to $70{ }^{\circ} \mathrm{C}$. The mean particle size of resulting Au nanoparticles increased from $2.3 \mathrm{~nm}$ to $3.3 \mathrm{~nm}$ respectively. ${ }^{28}$ Therefore, both room temperature (RT) and $70{ }^{\circ} \mathrm{C}$ were investigated so that the effect of small changes to the nanoparticle size on the resultant methane oxidation activity could be established. The mean particle size of 1\%AuPd/P25-RTdried and 1\%AuPd/P25-70-dried catalysts are reported in Table 1 (Entries 3 and 7). These were calculated from representative TEM images (see supporting information Fig. S2a and Fig. S3a) from approximately 250 particles. Increasing the catalyst preparation temperature from $\mathrm{RT}$ to $70{ }^{\circ} \mathrm{C}$ increased the mean particle size from $4.0 \mathrm{~nm}$ to $5.2 \mathrm{~nm}$, consistent with the previously reported size increase by Rogers et al. ${ }^{28}$ The dried-only catalysts possess a particle size distribution of 2-10 nm, as shown in Figure S2a and S3a. This profile is also consistent with previously published reports where catalysts were prepared using stabiliser-free methods for sol-immobilisation. ${ }^{29}$

Initially, control reactions with no catalyst or just the support, $\mathrm{TiO}_{2}$, were carried out (Table 1, Entries 1 and 2), where no oxygenates were observed. The small quantity of $\mathrm{CO}_{2}$ detected was considered to be adventitious. The dried-only catalysts were then screened for methane oxidation and the catalytic activity data is presented in Table 1 (Entries 3 and 7). Despite the almost complete decomposition of $\mathrm{H}_{2} \mathrm{O}_{2}$ over both catalysts, no selective oxidation products were detected. We consider that the small particle size of the AuPd alloy could facilitate a rapid decomposition of the $\mathrm{H}_{2} \mathrm{O}_{2}$ to $\mathrm{H}_{2} \mathrm{O}$, which would prevent the possibility of methane reacting with active hydroperoxyl- or hydroxyl-radicals. ${ }^{30,31}$ Previously, it was shown that such materials exhibit high rates of $\mathrm{H}_{2} \mathrm{O}_{2}$ productivity in the direct synthesis of $\mathrm{H}_{2} \mathrm{O}_{2}$, as well as high $\mathrm{H}_{2} \mathrm{O}_{2}$ decomposition rates $\left(>100 \mu \mathrm{mol} \mathrm{min}^{-1}\right){ }^{31}$

Larger modifications to the mean particle size were achieved through post-synthesis heat treatments at 400,600 or $800{ }^{\circ} \mathrm{C}$. The catalysts calcined at $400{ }^{\circ} \mathrm{C}$ (Table 1, Entries 4 and 8 ) did not produce oxygenates, despite an increase in the metal nanoparticle size to $6.5 \mathrm{~nm}$ and $7.5 \mathrm{~nm}$ respectively. As with the dried-only catalysts, there was no $\mathrm{H}_{2} \mathrm{O}_{2}$ remaining after the reaction. The complete decomposition of $\mathrm{H}_{2} \mathrm{O}_{2}$ by the dried-only catalysts and catalysts calcined at $400{ }^{\circ} \mathrm{C}$ is typical of materials with small particle sizes ${ }^{31}$ and explains the low productivities observed for methane oxidation (0.054 $\left.\mathrm{mol} \mathrm{kg}_{\mathrm{cat}^{-1}} \mathrm{~h}^{-1}\right)$. 
Table 1: The effect of post-synthesis heat treatment on the catalytic activity of $1 \mathrm{wt} . \% \mathrm{AuPd} / \mathrm{TiO}{ }_{2}(\mathrm{P} 25)$ for the oxidation of methane. ${ }^{[\mathrm{al}}$ (Entries $3-6$; room temperature, $7-10 ; 70^{\circ} \mathrm{C}$ )

\begin{tabular}{|c|c|c|c|c|c|c|c|c|c|c|c|}
\hline Entry & $\begin{array}{c}\text { Heat } \\
\text { Treatment }\end{array}$ & Methanol $^{[\mathrm{b}]}$ & $\begin{array}{l}\text { Formic } \\
\text { Acid }^{[b]}\end{array}$ & $\begin{array}{l}\text { ts [ } \mu \mathrm{mol}] \\
\text { Methyl } \\
\text { hydroperoxide } \\
{[\mathrm{b}]}\end{array}$ & $\mathrm{CO}_{2}{ }^{[c]}$ & $\begin{array}{c}\text { Oxygenate } \\
\text { selectivity }{ }^{[\mathrm{d}]} \\
{[\%]}\end{array}$ & $\begin{array}{c}\text { Total } \\
\text { Productivity } \\
\left.\left[\mathrm{mol} \mathrm{kg}_{(\mathrm{cat})}\right)^{-1} \mathrm{~h}^{-1}\right]\end{array}$ & $\begin{array}{l}\text { TOF }^{[f]} \\
{\left[\mathrm{h}^{-1}\right]}\end{array}$ & $\begin{array}{c}\mathrm{H}_{2} \mathrm{O}_{2} \\
\text { Remaining } \\
{[\%]}\end{array}$ & $\begin{array}{c}\text { Mean } \\
\text { Particle } \\
\text { Size }{ }^{[\mathrm{h}]} \\
{[\mathrm{nm}]}\end{array}$ & $\begin{array}{c}\mathrm{H}_{2} \mathrm{O}_{2} \\
\text { Decompositi } \\
\text { on Rate }{ }^{[g][\mathrm{i}]} \\
{\left[\mu \mathrm{mol} \mathrm{min}^{-1}\right]}\end{array}$ \\
\hline 1 & Blank & 0 & 0 & 0 & 0.24 & 0 & 0 & 0 & 97.6 & $\mathrm{n} / \mathrm{a}$ & $\mathrm{n} / \mathrm{a}$ \\
\hline 2 & $\mathrm{TiO}_{2}$ & 0 & 0 & 0 & 0.20 & 0 & 0.039 & 0 & 97.4 & $\mathrm{n} / \mathrm{a}$ & $\mathrm{n} / \mathrm{a}$ \\
\hline 3 & RT, Dried & 0 & 0 & 0 & 0.27 & 0 & 0.054 & 0.78 & 0.3 & $4.0 \pm 1.4$ & 557 \\
\hline 4 & $\mathrm{RT}, 400^{\circ} \mathrm{C}$ & 0 & 0 & 0 & 0.27 & 0 & 0.054 & 0.77 & 0.3 & $6.5 \pm 2.1$ & 199 \\
\hline 5 & $\mathrm{RT}, 600^{\circ} \mathrm{C}$ & 0.03 & 0 & 0.13 & 0.16 & 46.6 & 0.063 & 0.91 & 1.7 & $8.3 \pm 2.0$ & 105 \\
\hline 6 & $\mathrm{RT}, 800^{\circ} \mathrm{C}$ & 0.23 & 0 & 0.50 & 0.17 & 80.8 & 0.172 & 2.47 & 42.1 & $19.0 \pm 5.1$ & 99 \\
\hline 7 & $70^{\circ} \mathrm{C}$, Dried & 0 & 0 & 0 & 0.16 & 0 & 0.032 & 0.50 & 0.3 & $5.2 \pm 1.4$ & 278 \\
\hline 8 & $70^{\circ} \mathrm{C}, 400^{\circ} \mathrm{C}$ & 0 & 0 & 0 & 0.14 & 0 & 0.018 & 0.28 & 0.5 & $7.5 \pm 2.0$ & 251 \\
\hline 9 & $70^{\circ} \mathrm{C}, 600^{\circ} \mathrm{C}$ & 0 & 0 & 0.12 & 0.16 & 42.5 & 0.057 & 0.89 & 13.3 & $11.1 \pm 2.4$ & 145 \\
\hline 10 & $70^{\circ} \mathrm{C}, 800^{\circ} \mathrm{C}$ & 0.29 & 0 & 1.12 & 0.16 & 90.0 & 0.312 & 4.87 & 56.1 & $19.7 \pm 6.2$ & 31 \\
\hline
\end{tabular}

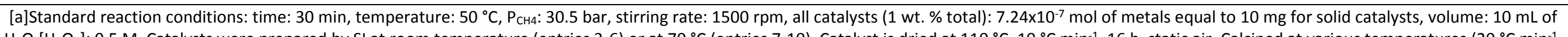

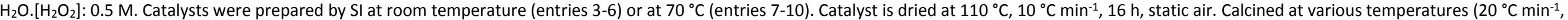

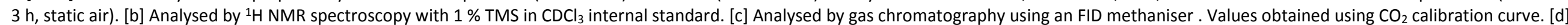

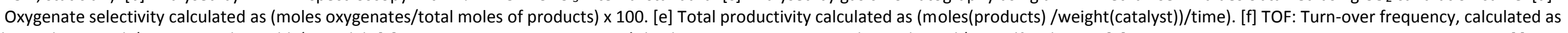

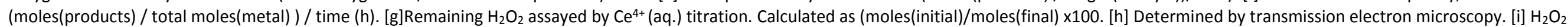

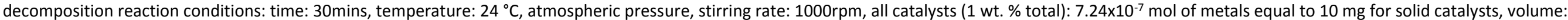
$10 \mathrm{~mL}$ of $\mathrm{H}_{2} \mathrm{O} .\left[\mathrm{H}_{2} \mathrm{O}_{2}\right]: 0.5 \mathrm{M}$. Maximum experimental error; Methanol: $10 \%$, Methyl Hydroperoxide: $16 \%, \mathrm{CO}_{2}: 22 \%, \mathrm{H}_{2} \mathrm{O}_{2}: 9 \%$. 
In order to better establish the relative rate of $\mathrm{H}_{2} \mathrm{O}_{2}$ decomposition, a series of control experiments at room temperature were performed. The catalysts were stirred in a dilute $\mathrm{H}_{2} \mathrm{O}_{2}$ solution and the decomposition rate was determined through analysis of the solution as a function of time. The decomposition rates expressed as $\mu \mathrm{mol} \mathrm{min}^{-1}$ are reported in Table 1 and the time-on-line data is shown in supporting information Figure S4 and S5. The rate of $\mathrm{H}_{2} \mathrm{O}_{2}$ decomposition over 1\%AuPd/P25-RT-dried was found to be $557 \mu \mathrm{mol} \mathrm{min}^{-1}$ and 278 $\mu \mathrm{mol} \mathrm{min}-1$ for $1 \% A u P d / P 25-70-d r i e d$. Less than $10 \%$ of the $\mathrm{H}_{2} \mathrm{O}_{2}$ was remaining after 30 min and indicates that the small AuPd particles are capable of rapidly decomposing $\mathrm{H}_{2} \mathrm{O}_{2}$.

Following heat treatment at $600{ }^{\circ} \mathrm{C}$ (Table 1, Entries 5 and 9) the particle sizes of the catalysts increased to $c a .10 \mathrm{~nm}$, where the onset of catalytic activity was observed, albeit with low productivity and relatively high $\mathrm{H}_{2} \mathrm{O}_{2}$ decomposition rates. The rate of $\mathrm{H}_{2} \mathrm{O}_{2}$ decomposition decreased to $c a .100 \mu \mathrm{mol} \mathrm{min}{ }^{-1}$ over these catalysts, although just $1.7 \%$ of $\mathrm{H}_{2} \mathrm{O}_{2}$ remained after the oxidation reaction. The rate of $\mathrm{H}_{2} \mathrm{O}_{2}$ decomposition over catalysts with metal nanoparticles less than $8 \mathrm{~nm}$ in diameter is unfavourably high and does not facilitate the production of methanol.

Heat treatment at $800{ }^{\circ} \mathrm{C}$ (Table 1, Entries 6 and 10) resulted in a significant growth of the mean nanoparticle size to ca. $19 \mathrm{~nm}$ in 1\%AuPd/P25-RT-800 and 1\%AuPd/P25-70-800 catalysts, which was matched by a large improvement in catalyst productivity $(0.172 \mathrm{~mol}$ and $0.312 \mathrm{~kg}_{\text {cat }}{ }^{-1} \mathrm{~h}^{-1}$ respectively), as well as oxygenate selectivity and remaining $\mathrm{H}_{2} \mathrm{O}_{2}$. The $\mathrm{H}_{2} \mathrm{O}_{2}$ decomposition rates of the 1\%AuPd/P25-RT-800 and 1\%AuPd/P25-70-800 were found to be ca. 100 and $30 \mu \mathrm{mol} \mathrm{min} \mathrm{m}^{-1}$ respectively, which emphasises that larger nanoparticles are required to ensure a sufficient concentration of reactive oxidising radicals, which facilitates the activation of methane.

Particle size distributions for both 1\%AuPd/P25-RT-800 and 1\%AuPd/P25-70-800 (Fig. S1d and S2d) demonstrate quite similar profiles and average particle sizes: $19.0 \pm 5.1$ and $19.7 \pm$ $6.2 \mathrm{~nm}$, respectively. Upon closer inspection, however, the presence of nanoparticles below $9 \mathrm{~nm}$ in the 1\%AuPd/P25-RT-800 catalyst were observed, in contrast to 1\%AuPd/P25-70-800. The presence of these sub-10 $\mathrm{nm}$ particles could be a contributing factor in the lower activity observed with 1\%AuPd/P25-RT-800, as these particles demonstrably catalyse the deleterious decomposition of $\mathrm{H}_{2} \mathrm{O}_{2}$, however the number of sub-10 $\mathrm{nm}$ metal nanoparticles in 1\%AuPd/P25-RT-800 represents a small proportion of the total population of supported 
nanoparticles. Another possible explanation concerns the standard deviation of the average particle size measurements, which suggests that the actual differences in the supported nanoparticle sizes are greater than suggested by the average value. There are, however, clear trends associated with the average particle sizes, the rates of $\mathrm{H}_{2} \mathrm{O}_{2}$ decomposition and the quantity of reaction products. These relationships are illustrated in Figure $1 \mathrm{a}), \mathrm{b}$ ) and c).
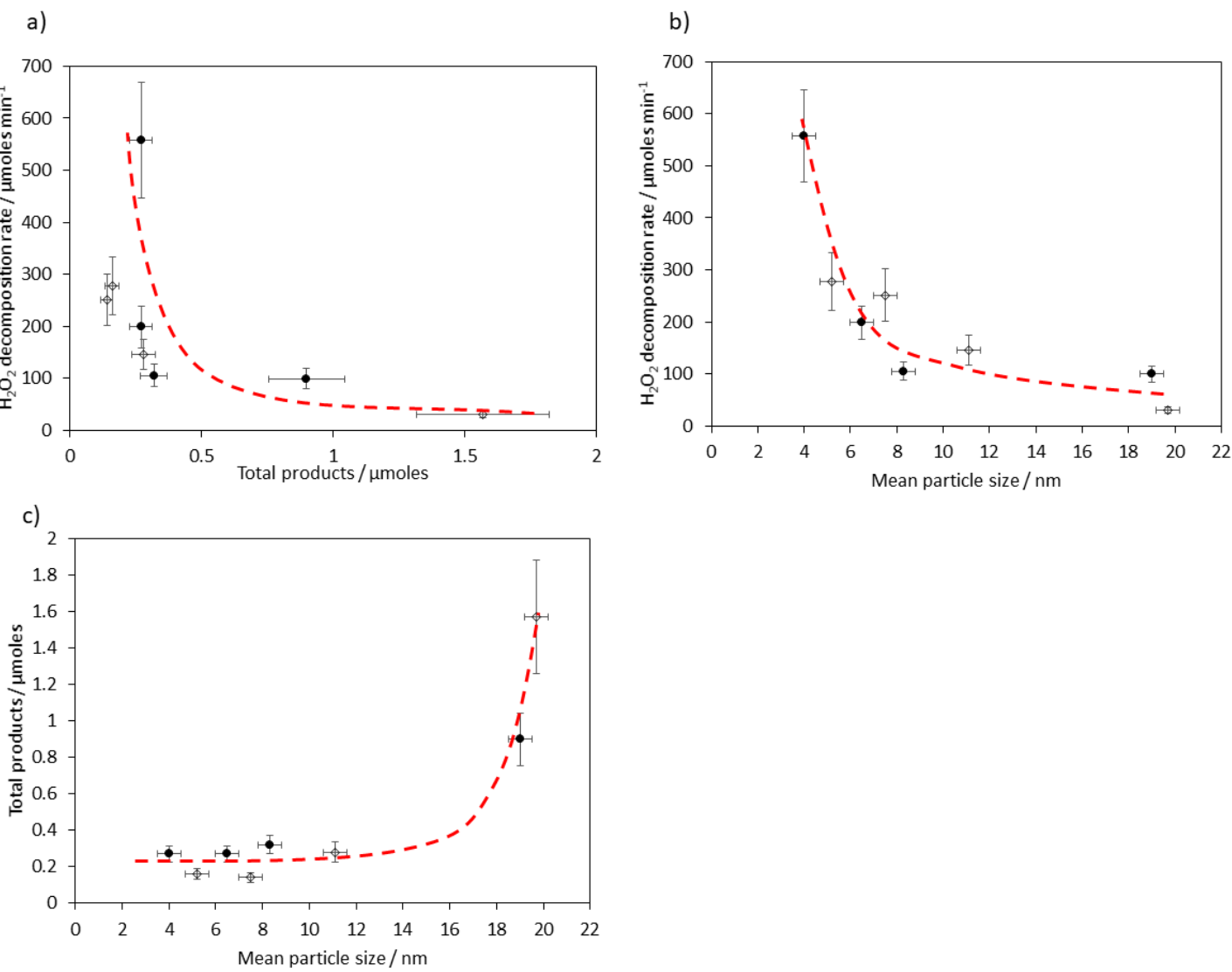

Fig. 1. The structure-activity relationship of 1 wt. \% AuPd/ $\mathrm{TiO}_{2}$ (P25) for methane oxidation: a) $\mathrm{Lower}_{2} \mathrm{H}_{2} \mathrm{O}_{2}$ decomposition rates are consistent with the larger quantities of products after the $0.5 \mathrm{~h}$ reaction; b) $\mathrm{Lower}_{2} \mathrm{H}_{2} \mathrm{O}_{2}$ decomposition rates lead to a higher productivity after the 30 min reaction; c) Larger mean particle sizes result in higher productivities. $\bullet=\mathrm{RT}$ and $\diamond=70^{\circ} \mathrm{C}$.

The oxidation state of $\mathrm{Pd}$ has previously been demonstrated to affect the rate of $\mathrm{H}_{2} \mathrm{O}_{2}$ decomposition ${ }^{32,33}$. XPS was therefore used to investigate a potential link between $\mathrm{H}_{2} \mathrm{O}_{2}$ decomposition rates (and therefore oxygenate production) and the oxidation state of $\mathrm{Pd}$ in the samples. The corresponding $\mathrm{Au} 4 \mathrm{~d}$ and $\mathrm{Pd} 3 \mathrm{~d}$ spectra are illustrated in Figure $\mathrm{S} 7$ and $\mathrm{S} 8$, with elemental analysis provided in Table S2. It is evident that the preparation method, involving $\mathrm{NaBH}_{4}$ as the reducing agent, leads to the formation of the reduced metal species only. Expectedly, calcination of the catalysts resulted in the formation of oxidised species, with only $\mathrm{Pd}^{2+}$ present after calcination at $400{ }^{\circ} \mathrm{C}$ (Fig. S7 and S8) (Table S2, Entries 2-4 and 6- 
8). Overall, the XPS analysis of $\mathrm{Pd} 3 \mathrm{~d}$ region of the $\mathrm{RT}$ and $70{ }^{\circ} \mathrm{C}$ prepared samples was similar and the oxidation state of the Pd was not affected by the temperature of the preparation method. In order to confirm the metal loadings and Au:Pd ratio, elemental analysis was carried out on the dried samples using MP-AES after digestion of the catalysts using aqua regia. Due to inefficient digestion of $\mathrm{TiO}_{2}$ support when using aqua regia, complementary SEM-EDX analysis was also carried out. The measured metal loadings are presented in Table S2 and are very close to that of the nominal values, although the 1\%AuPd-P25-70-800 had a lower loading (0.89 wt.\%) than 1\%AuPd-P25-RT-800 (0.97 wt.\%). Additionally, these SEM-EDX measurements were also consistent with the MP-AES data. The lower loading of metal in 1\%AuPd-P25-70-800 could actually be beneficial as there are fewer sites to decompose $\mathrm{H}_{2} \mathrm{O}_{2}$ in the system. It was previously reported that increasing the mass of 5 wt. $\% \mathrm{AuPd} / \mathrm{TiO} \mathrm{O}_{2}$ catalysts could lower the production of methanol. ${ }^{18}$ The importance of the concentration of metal is discussed below. TOFs were calculated according to the total metal loading determined using MP-AES (Table 1). The most active catalyst, 1\%AuPd-P25-70-800, exhibited a TOF of $4.87 \mathrm{~h}^{-1}$, comparable to those previously reported. ${ }^{20}$

\section{The effect of the support phase}

The increase in oxygenate productivity noted when the 1 wt. \% AuPd/TiO 2 (P25) catalysts were calcined at $800{ }^{\circ} \mathrm{C}$ was ascribed to the increase in mean AuPd particle size, which prevented the deleterious decomposition of $\mathrm{H}_{2} \mathrm{O}_{2}$. However, the $\mathrm{P} 25 \mathrm{TiO}_{2}$ support also underwent a phase transition to rutile, as evidenced by the characteristic XRD reflections (Fig. S6). Therefore, an analogous series of catalysts were prepared on rutile $\mathrm{TiO}_{2}$. Nitrogen adsorption measurements indicated that the BET surface area decreased from $45 \mathrm{~m}^{2} \mathrm{~g}^{-1}$ for the P25 material to $6 \mathrm{~m}^{2} \mathrm{~g}^{-1}$ for the rutile material. Catalysts were prepared with $1 \mathrm{wt}$.\% AuPd at both room temperature and at $70{ }^{\circ} \mathrm{C}$ for consistency with the previous samples and were tested for the selective oxidation of methane with $\mathrm{H}_{2} \mathrm{O}_{2}$ (Table 2) after the same heat treatments. The XRD patterns of the supported rutile catalysts are shown in Fig. S9, and indicate that no major phase changes occur to the catalyst support. Consistent with the results in Table 1, selective methane oxidation over 1 wt.\% AuPd/rutile was not observed for the dried-only catalysts prepared at RT or $70{ }^{\circ} \mathrm{C}$ (Table 2, Entries 2 and 6). These catalysts exhibited high $\mathrm{H}_{2} \mathrm{O}_{2}$ decomposition activity (Fig. $\mathrm{S} 12$ and S13), which we consider is due to the 
particle size and presence ofmetallic Pd in the AuPd nanoparticles. Analysis of the rutilesupported catalysts by TEM revealed an interesting phenomenon that occurs during preparation (Fig. S10 and S11). Deposition of stabiliser-free AuPd sols onto the rutile $\mathrm{TiO}_{2}$ support resulted in particle agglomerates on the dried-only catalyst, rather than discrete nanoparticles. Heat treatment of these parent catalysts subsequently resulted in the preferential formation of distinct, hemi-spherical nanoparticles, which increase in size with increasing heat treatment temperatures (Fig. S10 and S11). Interestingly, the AuPd/rutile catalysts calcined at $400{ }^{\circ} \mathrm{C}$ exhibited selective catalytic activity towards oxygenates (Table 2 , Entries 3-5 and 7-9), in contrast to the analogous catalysts supported on P25. After calcination at $800{ }^{\circ} \mathrm{C}$, the mean particle size increased to $19-23 \mathrm{~nm}$, consistent with the catalysts supported on the untreated $\mathrm{TiO}_{2}$ support. 
Table 2: The effect of support pre-calcination for $1 \mathrm{wt} . \% \mathrm{AuPd} /$ rutile $\mathrm{TiO}_{2}$ prepared at room temperature $($ Entries $2-5)$ and at $70{ }^{\circ} \mathrm{C}(\mathrm{Entries} 6-9)^{[\mathrm{a}]}$

\begin{tabular}{|c|c|c|c|c|c|c|c|c|c|c|c|}
\hline \multirow{2}{*}{ Entry } & \multirow{2}{*}{$\begin{array}{l}\text { Heat } \\
\text { Treatment }\end{array}$} & \multicolumn{4}{|c|}{ Products $[\mu \mathrm{mol}]$} & \multirow{2}{*}{$\begin{array}{l}\text { Oxygenate } \\
\text { selectivity } \\
{[\text { [d] }[\%]}\end{array}$} & \multirow{2}{*}{$\begin{array}{c}\text { Total } \\
\text { Productivity } \\
{[\mathrm{e}]} \\
{\left[\begin{array}{c}\mathrm{mol} \mathrm{kg}_{(\mathrm{cat})}{ }^{-1} \\
\left.\mathrm{~h}^{-1}\right]\end{array}\right.}\end{array}$} & \multirow{2}{*}{$\begin{array}{l}\text { TOF }^{[f]} \\
{\left[h^{-1}\right]}\end{array}$} & \multirow{2}{*}{$\begin{array}{c}\mathrm{H}_{2} \mathrm{O}_{2} \\
\text { Remaining } \\
{[\%]}\end{array}$} & \multirow{2}{*}{$\begin{array}{c}\text { Mean Particle } \\
\text { Size }{ }^{[\mathrm{h}]} \\
{[\mathrm{nm}]}\end{array}$} & \multirow{2}{*}{ 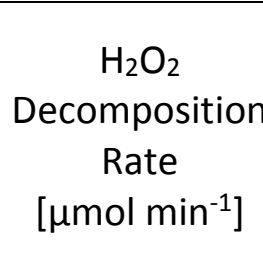 } \\
\hline & & Methanol[b] & $\begin{array}{l}\text { Formic } \\
\text { Acid }^{[b]}\end{array}$ & $\begin{array}{c}\text { Methyl } \\
\text { hydroperoxide }^{[b]}\end{array}$ & $\mathrm{CO}_{2}{ }^{[\mathrm{c}]}$ & & & & & & \\
\hline 1 & rutile & 0 & 0 & 0 & 0.33 & 0 & 0.040 & 0 & 97.5 & $\mathrm{n} / \mathrm{a}$ & $\mathrm{n} / \mathrm{a}$ \\
\hline 2 & RT, Dried & 0 & 0 & 0 & 0.26 & 0 & 0.052 & 0.73 & 0.2 & $\mathrm{n} / \mathrm{a}$ & 830 \\
\hline 3 & $\mathrm{RT}, 400^{\circ} \mathrm{C}$ & 0.26 & 0 & 0 & 0.29 & 47.9 & 0.109 & 1.51 & 2.2 & $8.7 \pm 3.9$ & 251 \\
\hline 4 & $\mathrm{RT}, 600^{\circ} \mathrm{C}$ & 0.22 & 0 & 0.36 & 0.31 & 65.4 & 0.176 & 2.45 & 4.5 & $10.4 \pm 2.3$ & 147 \\
\hline 5 & $\mathrm{RT}, 800^{\circ} \mathrm{C}$ & 0.45 & 0 & 0.21 & 0.18 & 83.4 & 0.163 & 2.27 & 2.1 & $19.6 \pm 5.9$ & 317 \\
\hline 6 & $70^{\circ} \mathrm{C}$, Dried & 0 & 0 & 0 & 0.27 & 0 & 0.053 & 0.83 & 0.2 & $\mathrm{n} / \mathrm{a}$ & 530 \\
\hline 7 & $70^{\circ} \mathrm{C}, 400^{\circ} \mathrm{C}$ & 0.36 & 0 & 0.56 & 0.15 & 86.2 & 0.214 & 3.35 & 1.4 & $8.0 \pm 2.4$ & 236 \\
\hline 8 & $70^{\circ} \mathrm{C}, 600^{\circ} \mathrm{C}$ & 0.30 & 0 & 0.73 & 0.15 & 87.1 & 0.161 & 2.53 & 23.8 & $10.8 \pm 2.9$ & 243 \\
\hline 9 & $70^{\circ} \mathrm{C}, 800^{\circ} \mathrm{C}$ & 0.38 & 0 & 0.73 & 0.16 & 86.5 & 0.243 & 3.80 & 7.8 & $22.6 \pm 10.7$ & 158 \\
\hline
\end{tabular}

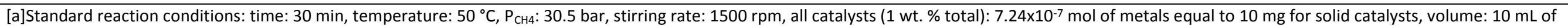

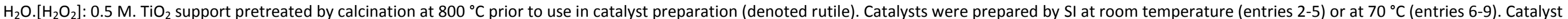

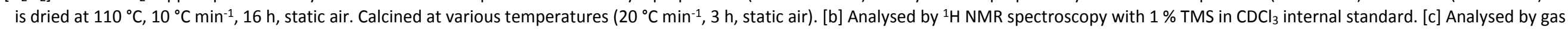

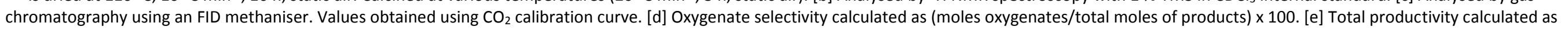

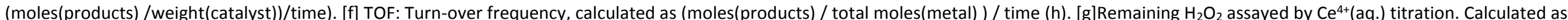

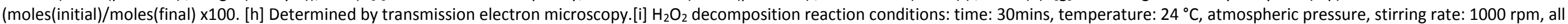

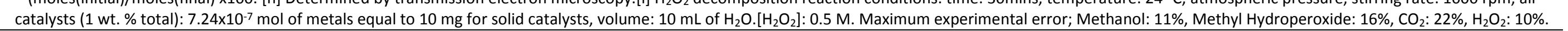


However, the concentration of $\mathrm{H}_{2} \mathrm{O}_{2}$ remaining is inconsistent with our earlier observations where the presence of larger AuPd particles resulted in high percentage of $\mathrm{H}_{2} \mathrm{O}_{2}$ remaining (Table 1). For example, the $1 \%$ AuPd-rutile-RT-800 catalyst had a mean particle size of $c a .20$ $\mathrm{nm}$ and exhibited high oxygenate selectivity, but with $<10 \% \mathrm{H}_{2} \mathrm{O}_{2}$ remaining (Table 2). The rate of $\mathrm{H}_{2} \mathrm{O}_{2}$ decomposition of the calcined catalysts was investigated and found to be between 150 and $317 \mu \mathrm{mol} \mathrm{min}{ }^{-1}$ for the catalysts prepared at room temperature and $70{ }^{\circ} \mathrm{C}$, respectively (Table 2, entries 3-5 and 7-9, and Fig. S12 and S13). The surface composition, as determined by XPS, indicates that between $40-60 \%$ of the $\mathrm{Pd}$ is present as $\mathrm{Pd}^{0}$ (Fig. S14 and S15, and Table S3), whereas the P25 supported catalysts were composed entirely of Pd ${ }^{2+}$. Previous studies on the direct synthesis of hydrogen peroxide have demonstrated $\mathrm{Pd}^{0}$ leads to higher rates of $\mathrm{H}_{2} \mathrm{O}_{2}$ decomposition compared to $\mathrm{Pd}^{2+} 34$ The expected effect on catalytic activity would be detrimental and result in inefficient utilisation of $\mathrm{H}_{2} \mathrm{O}_{2}$. To observe the effect of Pd oxidation state on the catalytic activity, two samples of 1\%AuPd/P25 were heated under a reducing environment $\left(5 \% \mathrm{H}_{2} / \mathrm{Ar}\right)$ at 400 or $800{ }^{\circ} \mathrm{C}$ and screened for methane oxidation. The results of these tests are presented in Table S4 and show almost complete consumption of $\mathrm{H}_{2} \mathrm{O}_{2}$, and almost no catalytic activity. These data confirm that $\mathrm{Pd}^{0}$ promotes $\mathrm{H}_{2} \mathrm{O}_{2}$ decomposition at the expense of methane oxidation activity.

The large mean particle sizes and the presence of $\mathrm{Pd}^{0}$ observed with the heat-treated catalysts supported on rutile $\mathrm{TiO}_{2}$ suggest that this combination can facilitate both the selective oxidation of methane whilst exhibiting an increased rate of $\mathrm{H}_{2} \mathrm{O}_{2}$ decomposition. This combination however does not facilitate efficient utilisation of $\mathrm{H}_{2} \mathrm{O}_{2}$. This is evident in Fig. 2, which depicts comparable relationships to those plotted in Fig. 1. The mean particle size of the rutile-supported catalysts does not correlate well with $\mathrm{H}_{2} \mathrm{O}_{2}$ decomposition or total products, as the Pd oxidation state is evidently an important parameter in determining these rates. Analogous elemental analysis using MP-AES and EDX was carried out on the rutile supported catalysts to confirm the expected metal loadings (Table S3). In each case, the metal loadings are close to the nominal loadings, although the catalysts prepared at $70{ }^{\circ} \mathrm{C}$ had a marginally lower total metal loading (0.91 wt. \%), consistent with the P25-supported catalysts, suggesting that the interaction of the nanoparticles and the support is less favourable at elevated temperatures. Additionally, the increased performance of the 1\%AuPd-rutile-70-800 compared with $1 \%$ AuPd-rutile-RT-800 could, in part, be due to the lower concentration of metal. Not only does this increase the TOF, but the lower metal 
loading is also consistent with higher productivity, which as suggested above, could contribute to suppressing the deleterious decomposition of $\mathrm{H}_{2} \mathrm{O}_{2}$.

a)

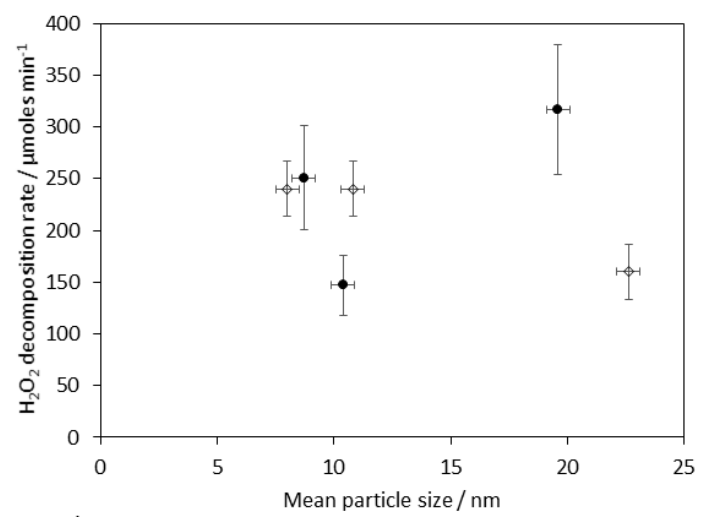

c)

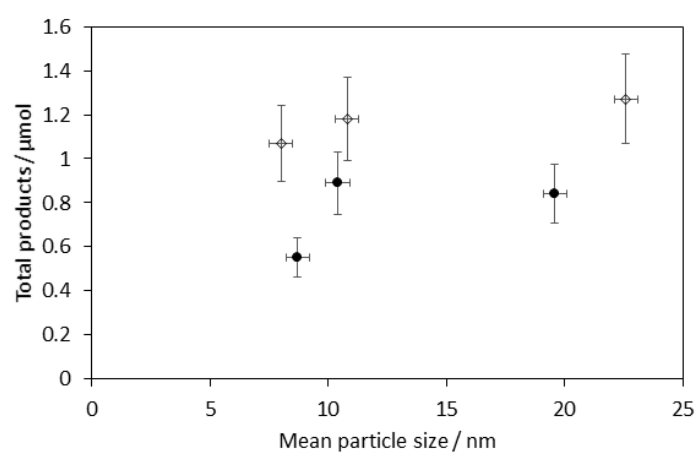

b)

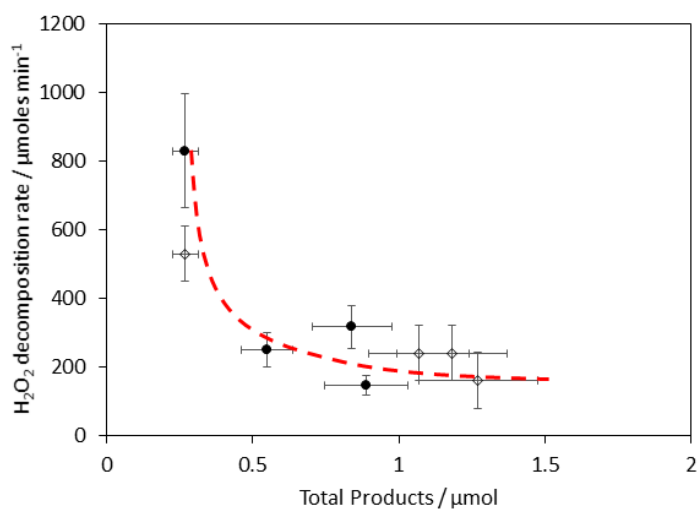

Fig. 2. The structure-activity relationship of $1 \mathrm{wt}$ \% $\mathrm{AuPd} / \mathrm{TiO}_{2}$ (rutile) for methane oxidation: a) In contrast to the $\mathrm{P} 25$-supported catalyst, there is not a clear correlation between the $\mathrm{H}_{2} \mathrm{O}_{2}$ decomposition rate and the mean particle size; b) The $\mathrm{H}_{2} \mathrm{O}_{2}$ decomposition rate correlates well with the total products after the $0.5 \mathrm{~h}$ reaction: $\mathrm{c}$ ) The correlation between mean particle size and total products for catalysts prepared on rutile is poor, indicating that there are other factors affecting the activity. $\bullet=\mathrm{RT}$ and $\diamond=70^{\circ} \mathrm{C}$.

The effect of surface area: metal loading ratio

The reduction in the surface area caused by the high temperature phase-change at $800{ }^{\circ} \mathrm{C}$ resulted in an increase in the supported metal to surface area ratio. Therefore, the metal loading on rutile $\mathrm{TiO}_{2}$ was reduced from $0.167 \% \mathrm{AuPd} \mathrm{m} \mathrm{m}^{-2}$ to the equivalent loading of 0.022 wt. \% AuPd m², which is consistent with the metal:surface area of the $1 \mathrm{wt}$. \% AuPd/P25 $\mathrm{TiO}_{2}$. In this case, a nominal 0.13 wt. \% loading of AuPd was used to prepare catalysts at room temperature on rutile $\mathrm{TiO}_{2}$. As expected, the mean AuPd particle sizes of the $0.13 \mathrm{wt}$. \% rutile $\mathrm{TiO}_{2}$ catalysts were comparable to the 1 wt. \% AuPd/P25 TiO 2 catalysts (Table 1 ) although interestingly, the dried catalyst featured nanoparticles that had formed agglomerates as was observed in the 1 wt.\% AuPd/rutile $\mathrm{TiO}_{2}$ catalysts. Fig. S16 illustrates the observed 
agglomeration, and similarly shows the formation of hemispherical nanoparticles after heat treatment at $400{ }^{\circ} \mathrm{C}$. The 0.13 wt. \% AuPd catalysts were active after calcination at $400{ }^{\circ} \mathrm{C}$ (Table 3), where the mean particle size was $6.5 \mathrm{~nm}$. Furthermore, the rate of $\mathrm{H}_{2} \mathrm{O}_{2}$ decomposition for all heat-treated catalysts was low and in general, > $90 \%$ remained after the 30 min reaction. The most likely explanation for this difference in catalytic activity is that the 0.13 wt. \% AuPd catalyst had significantly less metal present per moles of reactant and, therefore, the rate of $\mathrm{H}_{2} \mathrm{O}_{2}$ decomposition was lower. The total productivity was calculated to be $0.68 \mathrm{~mol} \mathrm{~kg}_{\mathrm{cat}}{ }^{-1} \mathrm{~h}^{-1}$, which corresponded to a turnover frequency of $103 \mathrm{~h}^{-1}$, significantly higher than the $1 \mathrm{wt}$. \% AuPd catalysts $\left(2-4 \mathrm{~h}^{-1}\right)$ and any previously reported supported-AuPd bimetallic catalyst for this reaction. ${ }^{18,20}$ As above, the TOFs were calculated according to the MP-AES measurements, which indicated the total metal loading to be $0.11 \mathrm{wt} . \%$, although at these very low loadings the limit of reliable quantification is approached. 
Table 3: The effect of reduced metal loading on pre-calcined support for the oxidation of methane $(0.13 \mathrm{wt} . \% \mathrm{AuPd} / \mathrm{rutile} \mathrm{TiO} 2)$ [a]

\begin{tabular}{|c|c|c|c|c|c|c|c|c|c|c|c|}
\hline \multirow{2}{*}{ Entry } & \multirow{2}{*}{$\begin{array}{c}\text { Heat } \\
\text { Treatment }\end{array}$} & \multicolumn{4}{|c|}{ Products [ $\mu \mathrm{mol}]$} & \multirow{2}{*}{$\begin{array}{c}\text { Oxygenate } \\
\text { selectivity }^{[\mathrm{d}]} \\
{[\%]}\end{array}$} & \multirow{2}{*}{$\begin{array}{c}\text { Total } \\
\text { Productivity } \\
\left.\left[\mathrm{mol} \mathrm{kg}_{(\text {cat })}\right)^{-1} \mathrm{~h}^{-1}\right]\end{array}$} & \multirow{2}{*}{$\begin{array}{l}\text { TOF }{ }^{[f]} \\
{\left[h^{-1}\right]}\end{array}$} & \multirow{2}{*}{$\begin{array}{c}\mathrm{H}_{2} \mathrm{O}_{2} \\
\text { Remaining } \\
{[\%]}\end{array}$} & \multirow{2}{*}{$\begin{array}{c}\text { Mean } \\
\text { Particle } \\
\text { Size }{ }^{[\mathrm{h}]} \\
{[\mathrm{nm}]} \\
\end{array}$} & \multirow{2}{*}{ 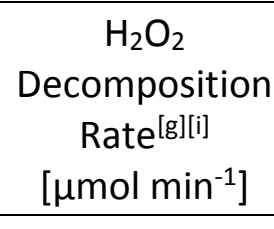 } \\
\hline & & Methanol ${ }^{[b]}$ & $\begin{array}{l}\text { Formic } \\
\text { Acid }^{[b]} \\
\end{array}$ & $\begin{array}{c}\text { Methyl } \\
\text { hydroperoxide }^{[b]}\end{array}$ & $\mathrm{CO}_{2}{ }^{[\mathrm{c}]}$ & & & & & & \\
\hline 1 & Dried & 0 & 0 & 0 & 0.23 & 0 & 0.046 & 7.00 & 8.9 & $\mathrm{n} / \mathrm{a}$ & 215 \\
\hline 2 & $400^{\circ} \mathrm{C}$ & 0.06 & 0.00 & 0.41 & 0.25 & 64.8 & 0.152 & 23.0 & 55.1 & $6.5 \pm 1.7$ & 10.7 \\
\hline 3 & $600{ }^{\circ} \mathrm{C}$ & 0.13 & 0.00 & 0.86 & 0.33 & 75.0 & 0.234 & 35.5 & 75.5 & $9.3 \pm 3.2$ & 25.9 \\
\hline 4 & $800^{\circ} \mathrm{C}$ & 0.32 & 0.19 & 2.65 & 0.27 & 90.7 & 0.677 & 103 & 64.3 & $19.1 \pm 4.5$ & 21.4 \\
\hline
\end{tabular}

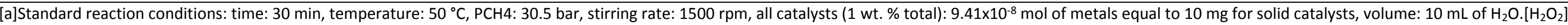

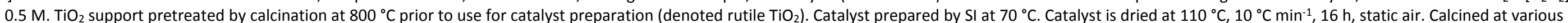

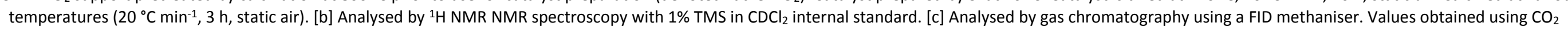

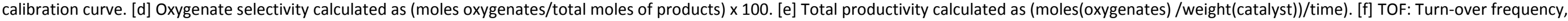

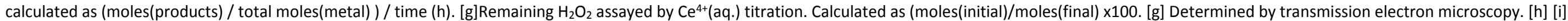

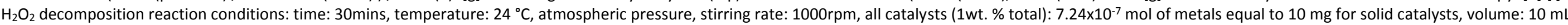
of $\mathrm{H}_{2} \mathrm{O}$. $\left[\mathrm{H}_{2} \mathrm{O}_{2}\right]: 0.5 \mathrm{M}$. Maximum experimental error; Methanol: $13 \%$, Formic Acid 2\%: , Methyl hydroperoxide: $15 \%, \mathrm{CO}_{2}: 20 \%, \mathrm{H}_{2} \mathrm{O}_{2}: 9 \%$. 
The rate of $\mathrm{H}_{2} \mathrm{O}_{2}$ decomposition at room temperature was much lower after calcination (Table 3, Fig. S17), as expected based on the methane oxidation reactions and the lower concentration of metal in the reaction. Over each catalyst, the rates were measured at $<26$ $\mu \mathrm{mol} \mathrm{min}^{-1}$ despite the presence of $c a .50 \% \mathrm{Pd}^{0}$, as shown from XPS analysis (Table S5 and Fig. S18). This is consistent with the 1 wt.\% AuPd/rutile $\mathrm{TiO}_{2}$ catalysts that also featured high concentrations of $\mathrm{Pd}^{0}$ after calcination, suggesting that rutile stabilises $\mathrm{Pd}^{0}$ (or inhibits $\mathrm{Pd}$ oxidation). In addition, the XRD patterns of the $0.13 \mathrm{wt} . \%$ AuPd catalysts exhibited the same reflections as those in the $1 \mathrm{wt} \%$ AuPd/rutle catalysts (Fig. S19). The reduction in metal loading also decreased the concentration of $\mathrm{H}_{2} \mathrm{O}_{2}$ decomposing metal, which facilitates a slower turnover of $\mathrm{H}_{2} \mathrm{O}_{2}$ and a higher methane oxidation activity. This observation supports the work of $\mathrm{Han}^{35}$ et al. and Landon ${ }^{36}$ et al. who demonstrated the proportional increase in $\mathrm{H}_{2} \mathrm{O}_{2}$ hydrogenation with increasing catalyst mass. The results from the present work indicates that the concentration of metal is an important parameter in determining methane oxidation activity in AuPd catalysts. This relationship is illustrated in Fig. 3, demonstrating the dependence of TOF as a function of the actual metal loading, as determined from MP-AES. Catalysts calcined at $800^{\circ} \mathrm{C}$ were selected due to a comparable metal nanoparticle size of $c a$. $20 \mathrm{~nm}$. Further inspection (Fig. 3, Inset) shows metal loadings closer to 1 wt. \% where it is evident that a lower metal loading is conducive to an improved TOF of methanol and is likely caused by a decrease in the rate of deleterious $\mathrm{H}_{2} \mathrm{O}_{2}$ decomposition. These findings further underline the sensitivity of this reaction to the properties of the catalyst. 


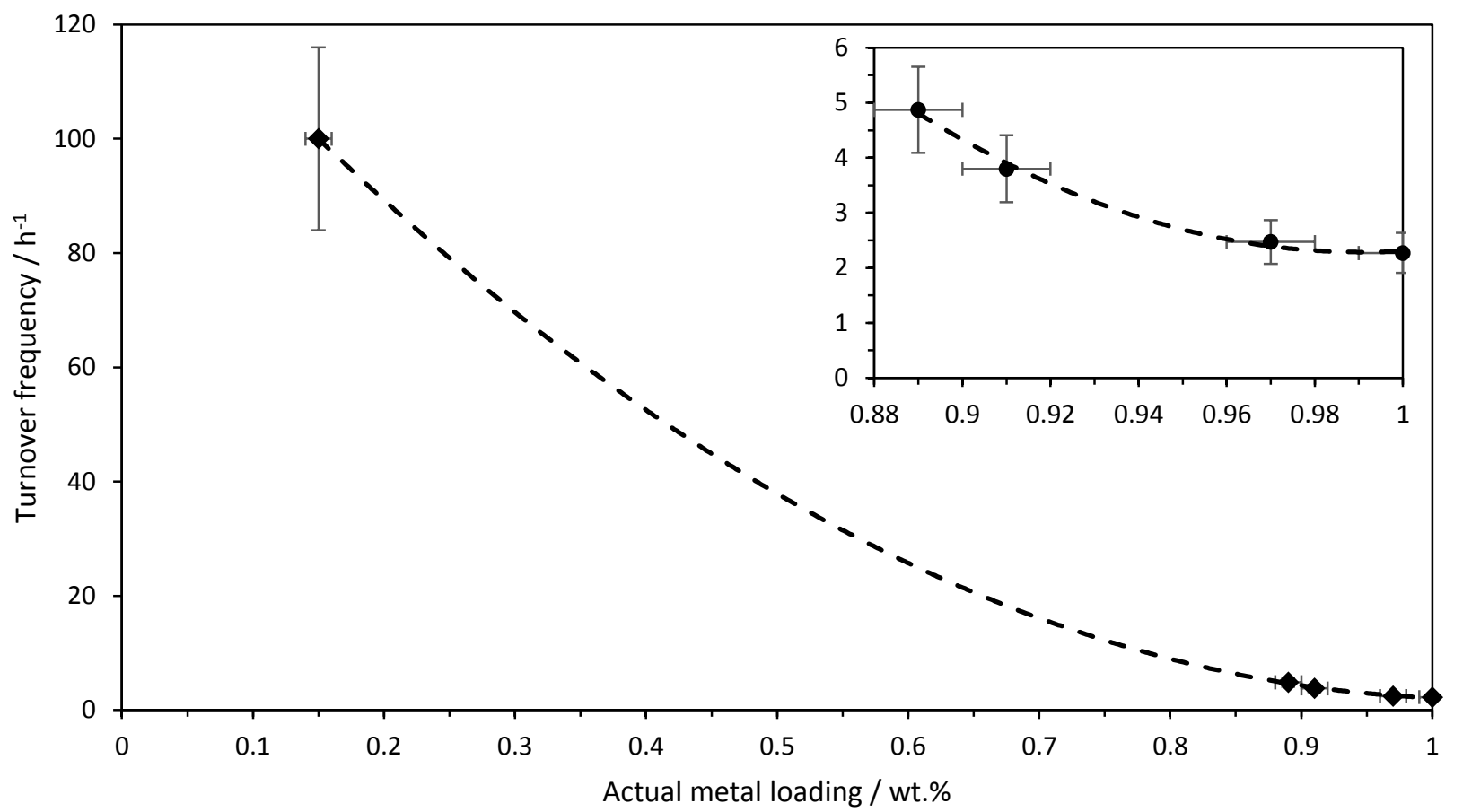

Fig. 3. The relationship between the actual metal loading determined using MP-AES and the TOF for a series of AuPd $/ \mathrm{TiO}_{2}$ catalysts calcined at $800{ }^{\circ} \mathrm{C}$ and with similar average particle sizes (ca. $20 \mathrm{~nm}$ ). Inset: Close-up of the graph where the metal loading is between 0.88 - 1 wt.\%. 


\section{Conclusions}

The influence of nanoparticle size and Pd oxidation state on the selective methane oxidation using $\mathrm{AuPd} / \mathrm{TiO}_{2}$ has been systematically investigated. Using stabiliser-free solimmobilisation, the initial particle size distribution was controlled and modification of the deposition temperature allowed small differences in the initial particle size to be induced. These dried-only catalysts were not active for methane oxidation due to their ability to rapidly decompose $\mathrm{H}_{2} \mathrm{O}_{2}$. Calcining the catalysts at 400,600 and $800{ }^{\circ} \mathrm{C}$ resulted in significant increases in the mean particle sizes, which yielded improvements in the $\mathrm{H}_{2} \mathrm{O}_{2}$ stability. In catalysts with larger than $c a .10 \mathrm{~nm}$ metal nanoparticles, the production of oxygenates was observed. After calcination at $800{ }^{\circ} \mathrm{C}$ the $\mathrm{P} 25 \mathrm{TiO}_{2}$ transformed from approximately $80 \%$ anatase and $20 \%$ rutile to $100 \%$ rutile. To understand the influence of the support phase, catalysts were prepared using calcined $\mathrm{P}_{2} 5 \mathrm{TiO}_{2}$, which produced a pure rutile phase. The stabilisation of $\mathrm{Pd}^{0}$ in these catalysts, even after high temperature calcination, resulted in rapid $\mathrm{H}_{2} \mathrm{O}_{2}$ decomposition. The metal loading was proportionally lowered to account for the lower surface area of the rutile catalyst compared to the P25 $\mathrm{TiO}_{2}$. These 0.13 wt.\% AuPd/rutile $\mathrm{TiO}_{2}$ catalysts exhibited extremely high activity, particularly when calcined at 800 ${ }^{\circ} \mathrm{C}$ : The TOF of $0.13 \% A u P d /$ rutile-RT-800 was $103 \mathrm{~h}^{-1}$. This is significantly higher than previously reported AuPd catalysts. We consider that the low concentration of metal in the low-loaded catalysts limited the $\mathrm{H}_{2} \mathrm{O}_{2}$ decomposition to a favourable rate. Therefore, while the supported nanoparticle size is an important parameter, it is not the only consideration that must be made in developing highly active, efficient heterogeneous catalysts for the selective oxidation of methane to methanol using supported AuPd nanoparticles. The size, oxidation state and concentration of supported nanoparticles must be controlled to maximise the efficiency and performance of the resulting catalyst.

\section{Acknowledgements}

The authors wish to thank ExxonMobil for financial support and the Cardiff University electron microscopy facility for the transmission (TEM) and scanning electron microscopy (SEM). 


\section{Associated Content}

Summary of prepared catalysts, typical ${ }^{1} \mathrm{H}$ NMR spectrum of post-reaction reaction solution, TEM, $\mathrm{H}_{2} \mathrm{O}_{2}$ decomposition reaction data, XRD, XPS, MP-AES and SEM-EDX analysis of catalysts. 


\section{References}

(1) da Silva, M. J. Synthesis of Methanol from Methane: Challenges and Advances on the MultiStep (Syngas) and One-Step Routes (DMTM). Fuel Process. Technol. 2016, 145, 42-61.

(2) Horn, R.; Schlögl, R. Methane Activation by Heterogeneous Catalysis. Catal. Letters 2015, 145, 23-39.

(3) Blanksby, S. J.; Ellison, G. B. Bond Dissociation Energies of Organic Molecules. Acc. Chem. Res. 2003, 36, 255-263.

(4) Tang, P.; Zhu, Q.; Wu, Z.; Ma, D. Methane Activation: The Past and Future. Energy Environ. Sci. 2014, 7, 2580-2591.

(5) Wilhelm, D. J.; Simbeck, D. R.; Karp, A. D.; Dickenson, R. L. Syngas Production for Gas-toLiquids Applications: Technologies, Issues and Outlook. Fuel Process. Technol. 2001, 71, 139148.

(6) Sheldon, D. Methanol Production - A Technical History. Johnson Matthey Technol. Rev. 2017, 61, 172-182.

(7) BP Statistical Review of World Energy June 2017. https://www.bp.com/content/dam/bp/en/corporate/pdf/energy-economics/statisticalreview-2017/bp-statistical-review-of-world-energy-2017-full-report.pdf.

(8) N. F. Goldshle, A. A. Shteinman, A. E.; Shilov, V. V. E. No Title. Russ. J. Phys. Chem. USSR 1972, 46, 785-786.

(9) Shilov, A. E.; Shul'pin, G. B. Activation of C-H Bonds by Metal Complexes. Chem. Rev. 1997, 97, 2879-2932.

(10) Periana, R. A.; Taube, D. J.; Evitt, E. R.; Löffler, D. G.; Wentrcek, P. R.; Voss, G.; Masuda, T.; L6ffler, D. G. A Mercury-Catalyzed, High-Yield System for the Oxidation of Methane to Methanol. Science. 1993, 259, 340-343.

(11) Periana, R. A.; Taube, D. J.; Gamble, S.; Taube, H.; Satoh, T.; Fujii, H. Platinum Catalysts for the High-Yield Oxidation of Methane to a Methanol Derivative. Science. 1998, 280, 560-564.

(12) Hammond, C.; Forde, M. M.; Ab Rahim, M. H.; Thetford, A.; He, Q.; Jenkins, R. L.; Dimitratos, N.; Lopez-Sanchez, J. A.; Dummer, N. F.; Murphy, D. M.; et al. Direct Catalytic Conversion of Methane to Methanol in an Aqueous Medium by Using Copper-Promoted Fe-ZSM-5. Angew. Chemie - Int. Ed. 2012, 51, 5129-5133.

(13) Hammond, C.; Dimitratos, N.; Lopez-Sanchez, J. A.; Jenkins, R. L.; Whiting, G.; Kondrat, S. A.; Ab Rahim, M. H.; Forde, M. M.; Thetford, A.; Hagen, H.; et al. Aqueous-Phase Methane Oxidation over Fe-MFI Zeolites; Promotion through Isomorphous Framework Substitution. ACS Catal. 2013, 3, 1835-1844.

(14) Enache, D. I.; Barker, D.; Edwards, J. K.; Taylor, S. H.; Knight, D. W.; Carley, A. F.; Hutchings, G. J. Solvent-Free Oxidation of Benzyl Alcohol Using Titania-Supported Gold-palladium Catalysts: Effect of Au-Pd Ratio on Catalytic Performance. Catal. Today 2007, 122, 407-411.

(15) Dimitratos, N.; Lopez-Sanchez, J. A.; Hutchings, G. J. Selective Liquid Phase Oxidation with Supported Metal Nanoparticles. Chem. Sci. 2012, 3, 20-44.

(16) Kesavan, L.; Tiruvalam, R.; Rahim, M. H. A.; bin Saiman, M. I.; Enache, D. I.; Jenkins, R. L.; Dimitratos, N.; Lopez-Sanchez, J. A.; Taylor, S. H.; Knight, D. W.; et al. Solvent-Free Oxidation of Primary Carbon-Hydrogen Bonds in Toluene Using Au-Pd Alloy Nanoparticles. Science. 2011, 331, 195-199.

(17) Ab Rahim, M. H.; Forde, M. M.; Hammond, C.; Jenkins, R. L.; Dimitratos, N.; Lopez-Sanchez, J. A.; Carley, A. F.; Taylor, S. H.; Willock, D. J.; Hutchings, G. J. Systematic Study of the Oxidation of Methane Using Supported Gold Palladium Nanoparticles under Mild Aqueous Conditions. Top. Catal. 2013, 56, 1843-1857. 
(18) Ab Rahim, M. H.; Forde, M. M.; Jenkins, R. L.; Hammond, C.; He, Q.; Dimitratos, N.; LopezSanchez, J. A.; Carley, A. F.; Taylor, S. H.; Willock, D. J.; et al. Oxidation of Methane to Methanol with Hydrogen Peroxide Using Supported Gold-Palladium Alloy Nanoparticles. Angew. Chemie - Int. Ed. 2013, 52, 1280-1284.

(19) Edwards, J. K.; Solsona, B. E.; Landon, P.; Carley, A. F.; Herzing, A.; Kiely, C. J.; Hutchings, G. J. Direct Synthesis of Hydrogen Peroxide from $\mathrm{H}_{2}$ and $\mathrm{O}_{2}$ Using $\mathrm{TiO}_{2}$-Supported Au-Pd Catalysts. J. Catal. 2005, 236, 69-79.

(20) Ab Rahim, M. H.; Armstrong, R. D.; Hammond, C.; Dimitratos, N.; Freakley, S. J.; Forde, M. M.; Morgan, D. J.; Lalev, G.; Jenkins, R. L.; Lopez-Sanchez, J. A.; et al. Low Temperature Selective Oxidation of Methane to Methanol Using Titania Supported Gold Palladium Copper Catalysts. Catal. Sci. Technol. 2016, 6, 3410-3418.

(21) Agarwal, N.; Freakley, S. J.; McVicker, R. U.; Althahban, S. M.; Dimitratos, N.; He, Q.; Morgan, D. J.; Jenkins, R. L.; Willock, D. J.; Taylor, S. H.; et al. Aqueous Au-Pd Colloids Catalyze Selective $\mathrm{CH}_{4}$ Oxidation to $\mathrm{CH}_{3} \mathrm{OH}$ with $\mathrm{O}_{2}$ under Mild Conditions. Science. 2017, 358, 223-227.

(22) Villa, A.; Wang, D.; Veith, G. M.; Vindigni, F.; Prati, L. Sol Immobilization Technique: A Delicate Balance between Activity, Selectivity and Stability of Gold Catalysts. Catal. Sci. Technol. 2013, 3, 3036-3041.

(23) Signoretto, M.; Menegazzo, F.; Di Michele, A.; Fioriniello, E. Effects of Support and Synthetic Procedure for Sol-Immobilized Au Nanoparticles. Catalysts 2016, 6, 87.

(24) Campisi, S.; Ferri, D.; Villa, A.; Wang, W.; Wang, D.; Kröcher, O.; Prati, L. Selectivity Control in Palladium-Catalyzed Alcohol Oxidation through Selective Blocking of Active Sites. J. Phys. Chem. C 2016, 120, 14027-14033.

(25) Rogers, S. M.; Catlow, C. R. A.; Chan-Thaw, C. E.; Chutia, A.; Jian, N.; Palmer, R. E.; Perdjon, M.; Thetford, A.; Dimitratos, N.; Villa, A.; et al. Tandem Site- and Size-Controlled Pd Nanoparticles for the Directed Hydrogenation of Furfural. ACS Catal. 2017, 7, 2266-2274.

(26) He, Q.; Miedziak, P. J.; Kesavan, L.; Dimitratos, N.; Sankar, M.; Lopez-Sanchez, J. A.; Forde, M. M.; Edwards, J. K.; Knight, D. W.; Taylor, S. H.; et al. Switching-off Toluene Formation in the Solvent-Free Oxidation of Benzyl Alcohol Using Supported Trimetallic Au-Pd-Pt Nanoparticles. Faraday Discuss. 2013, 162, 365-378.

(27) Prati, L.; Villa, A. Gold Colloids: From Quasi-Homogeneous to Heterogeneous Catalytic Systems. Acc. Chem. Res. 2014, 47, 855-863.

(28) Rogers, S. M.; Catlow, C. R. A.; Chan-Thaw, C. E.; Gianolio, D.; Gibson, E. K.; Gould, A. L.; Jian, N.; Logsdail, A. J.; Palmer, R. E.; Prati, L.; et al. Tailoring Gold Nanoparticle Characteristics and the Impact on Aqueous-Phase Oxidation of Glycerol. ACS Catal. 2015, 5, 4377-4384.

(29) Abis, L.; Freakley, S. J.; Dodekatos, G.; Morgan, D. J.; Sankar, M.; Dimitratos, N.; He, Q.; Kiely, C. J.; Hutchings, G. J. Highly Active Gold and Gold-Palladium Catalysts Prepared by Colloidal Methods in the Absence of Polymer Stabilizers. Chem CatChem 2017, 15, 2914-2918.

(30) Hutchings, G. J.; Kiely, C. J. Strategies for the Synthesis of Supported Gold Palladium Nanoparticles with Controlled Morphology and Composition. Acc. Chem. Res. 2013, 46, 17591772.

(31) Pritchard, J.; Kesavan, L.; Piccinini, M.; He, Q.; Tiruvalam, R.; Dimitratos, N.; Lopez-Sanchez, J. A.; Carley, A. F.; Edwards, J. K.; Kiely, C. J.; et al. Direct Synthesis of Hydrogen Peroxide and Benzyl Alcohol Oxidation Using Au-Pd Catalysts Prepared by Sol Immobilization. Langmuir 2010, 26, 16568-16577.

(32) Choudhary, V. R.; Gaikwad, A. G.; Sansare, S. D. Activation of Supported Pd Metal Catalysts for Selective Oxidation of Hydrogen to Hydrogen Peroxide. Catal. Letters 2002, 83, 235-239.

(33) Samanta, C. Direct Synthesis of Hydrogen Peroxide from Hydrogen and Oxygen: An Overview of Recent Developments in the Process. Appl. Catal. A Gen. 2008, 350, 133-149.

(34) Samanta, C.; Choudhary, V. R. Direct Oxidation of $\mathrm{H}_{2}$ to $\mathrm{H}_{2} \mathrm{O}_{2}$ over $\mathrm{Pd} / \mathrm{CeO}_{2}$ Catalyst under 
Ambient Conditions: Influence of Halide Ions. Chem. Eng. J. 2008, 136, 126-132.

(35) Han, Y.-F.; Lunsford, J. H. Direct Formation of $\mathrm{H}_{2} \mathrm{O}_{2}$ from $\mathrm{H}_{2}$ and $\mathrm{O}_{2}$ over a $\mathrm{Pd} / \mathrm{SiO}_{2}$ Catalyst: The Roles of the Acid and the Liquid Phase. J. Catal. 2005, 230, 313-316.

(36) Landon, P.; Collier, P. J.; Carley, A. F.; Chadwick, D.; Papworth, A. J.; Burrows, A.; Kiely, C. J.; Hutchings, G. J. Direct Synthesis of Hydrogen Peroxide from $\mathrm{H}_{2}$ and $\mathrm{O}_{2}$ Using Pd and $\mathrm{Au}$ Catalysts. Phys. Chem. Chem. Phys. 2003, 5, 1917-1923. 
Graphical Abstract:

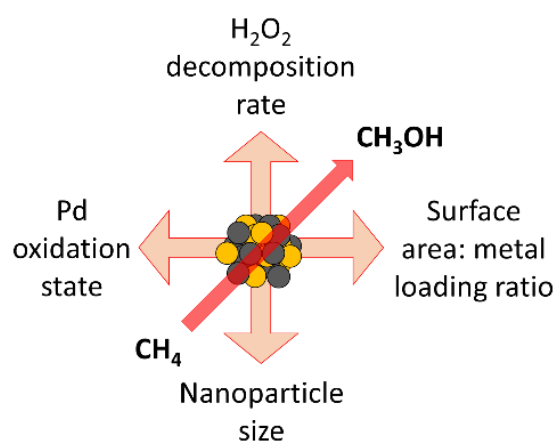

